\title{
Translation of Idioms: How They are Reflected in Movie Subtitling
}

\author{
Yana Shanti Manipuspika \\ Study Program of English, Faculty of Cultural Studies \\ Universitas Brawijaya, Malang, Indonesia \\ Correspondent Author: yana.manipuspika@gmail.com \\ Damai Reska Julia Winzami \\ Study Program of English, Faculty of Cultural Studies \\ Universitas Brawijaya, Malang, Indonesia
}

Received: $12 / 2 / 2020$

Accepted: $1 / 15 / 2021$

Published: 2/24/2021

\begin{abstract}
Idiomatic expressions are expressions with a figurative meaning different from their literal meaning, and therefore, they cannot be understood literally. This study aims to scrutinize some aspects of the translation of idiomatic expressions in a mystery movie entitled 'Murder on the Orient Express'. Seventy-seven idiomatic expressions were found in the movie. The idioms can be categorized as follows: keywords with idiomatic uses (16) idioms with nouns and adjectives (2), idiomatic pairs (1), idioms with prepositions (7), phrasal verbs idioms (26), verbal idioms (5), idioms from special subjects (1), idioms with key words from special categories (16), and idioms with comparison (3). Phrasal verbs idiom was the most frequently occurred because idioms are mostly organized by verb comprising the combination of verb and preposition or verb and adverb. Further, the rendering of the idioms from English as the Source Language (SL) into Indonesian as the Target Language (TL) employed some strategies; translation by paraphrase was the highly frequent translation strategy. The strategy of using an idiom of similar meaning but dissimilar form was also located in the high-frequency position of the continuum. Furthermore, using an idiom of similar form and meaning and translation by omission were the translation strategies of low frequency. Translation by paraphrase was frequently used because the translator wanted to convey the meaning as clearly as possible while also considering the cultural difference between SL and TL. To sum up, the idiomatic expression dominantly used in the movie was phrasal verbs (34\%), while the strategy that was mostly applied in translating them was translation by paraphrase (56\%). Keywords: figurative meaning, idioms, idiomatic translation, literal meaning, translation strategies

Cite as: Manipuspika, Y. S., \& . Winzami, D.R.J. (2021). Translation of Idioms: How They are Reflected in Movie Subtitling. Arab World English Journal for Translation \& Literary Studies 5 (1) 113-125. DOI: http://dx.doi.org/10.24093/awejtls/vol5no1.8
\end{abstract}




\section{Introduction}

Idioms can be found in daily life, from informal conversation to formal written text. They are an inalienable part of each language found in large numbers in most languages. However, idioms have meanings that sometimes depart from the literal meaning. Therefore, it is important to understand what is an idiom, how idioms carry meaning, and what translators do to maintain that meaning in another language. An idiom, also referred to as an idiomatic expression, is a set of words or phrases that has a figurative meaning conventionally understood by native speakers. Although the idiomatic expression is a universal feature of language, different languages may use literally different idiomatic expressions with similar referential meanings.

To know and understand the meaning of idioms, observing the context when the idiom is uttered is crucial. Additionally, some idioms have more than one meaning, thus the context in certain idiom is used to determine the intended meaning of that idiom. Translating idioms is not an easy task. This originates in the fact that each language has got some culture-specific items that are completely different from the corresponding items in another language. It is because idioms are a group of words that mean something different than the individual words it contains. According to Baker (2018), idioms are a frozen pattern of language which allows little or no variation in form and often carry meanings that cannot be deduced from their individual components. Therefore, idioms cannot be translated word-for-word, it has to be translated as a whole.

The complexities of idiomatic expressions make the rendering of the idiomaticity of expressions from a source into a target language so sophisticated and problematic at the same time. As stated by Shojaei (2012), the process of translating idioms from one language into another is a fine work which obliges a translator to have a good knowledge of both languages and cultures being shared or transferred as well as being able to identify and cope with the contingent problems in the process of finding an efficient equivalent for the inter-lingual idiomatic pairs. Taking these into consideration, this study aims at investigating the idioms and the strategies of translating the idioms in Murder on the Orient Express movie, a 2017 movie directed by Kenneth Branagh based on the 1934 novel of the same title and written by British writer, Agatha Christie. The novel was one of the most popular Agatha Christie's novels and had many adaptations in various forms such as TV series and films. The movie had set in the train to London in 1934. The movie selection was based on the setting, which is culturally different from TL (Indonesian) that would affect the translation. Also, the movie contains many unfamiliar idioms for viewers in the target language.

There are two research problems formulated in this study: 1) What are the types of idioms used in Murder on the Orient Express movie?; 2) What are the translation strategies used in translating the idiomatic expressions in the movie? 


\section{Literature Review}

Translation is the process of reproducing the receptor language the closest natural equivalent of the source language message, first in terms of meaning and secondly in terms of style (Nida \& Taber, 1982). This could be problematic when dealing with idioms. An idiom is a phrase or a fixed expression that has a figurative, or sometimes literal, meaning. According to Jabbari (2016), an idiom's figurative meaning is different from the literal meaning. They frequently occur in all languages. Idioms fall into the category of formulaic language.

There are various classifications of idioms proposed by some experts. This paper explores the idioms referring to Seidl \& McMordie's (1988) classification of idioms, which falls into 9 (nine) categories: 1) Key words with idiomatic uses, 2) Idioms with Nouns and Adjectives, 3) Idiomatic Pairs, 4) Idioms with Prepositions, 5) Phrasal Verbs Idiom, 6) Verbal Idioms, 7) Idioms from Special Subjects, 8) Idioms with Key Words from Special Categories, and 9) Idioms with Comparisons.

\section{Difficulties in Translating Idioms}

Idiomatic translation requires far more than the replacement of lexical and grammatical items between languages, and it may involve discarding the basic linguistic elements of the SL text. Baker (2018) classifies problems involved in translating idioms into four sub-categories.

First, an idiom may have no equivalence in the target language. Some idioms are bound to culture that do not exist in other places with different languages. For example, the idiom 'feather in (one's) cap'. This idiom means an exceptional achievement. This idiom is derived from the culture of some western countries indicating that placing a feather in one's cap is a sign of a significant achievement by the wearer. There is no equivalent for this idiom in Indonesian language. Even predicting the meaning of the idiom is unlikely for Indonesian because the act of putting a feather in a hat cannot be found anywhere in Indonesian culture.

Second, an idiom may have a similar counterpart in the target language, but its context of use may be different. In this case, the target language (TL) equivalence is available but is used in different situation and therefore, makes the idiom translation not applicable. The expressions in source and target language possibly have different connotations or may not be pragmatically transferable.

Third, an idiom may be used in the source text in both its literal and idiomatic senses at the same time. Unless the target language idiom corresponds to the source language idiom in form and meaning, the idiom cannot be successfully rendered in target language. Finally, the convention of using idioms in written discourse, the contexts in which they can be used, and their frequency of use may be different in the source and target languages.

Arab World English Journal for Translation \& Literary Studies 
To sum up, the main problems found in translating idioms and fixed expressions are the ability to recognize and interpret idioms correctly, and the difficulties involved in rendering the aspects of meaning that idioms or fixed expressions convey into the target language.

\section{Strategies for Translating Idiomatic Expressions}

Baker (2018) proposes four strategies for translating an idiom. The explanation is provided as the following.

1. Using an Idiom of Similar Form and Meaning

Baker (2018) states this strategy is composed by using an idiom in the target language that has the same meaning as the source language idiom. Also, it must consist of lexical items that is equivalent. This kind of match can only occasionally be achieved.

2. Using an Idiom of Similar Meaning but Dissimilar Form

It is often possible to find an idiom or fixed expression in the target language which has a meaning similar to that of the source idiom or expression, but which consist of different lexical items (Baker, 2018). In this case, the lexical items of idioms are not preserved; it is translated as a semantic equivalent.

3. Translation by Paraphrase

This translation strategy is the common way of translating idioms when a translator cannot find a match in the target language or when it seems inappropriate to use idiomatic language in the target language because of differences in stylistic preferences of the source and target language.

4. Translation by Omission

Baker (2018) mentions as with single words, an idiom may sometimes be omitted altogether in the target text. This may be because it has no close match in the target language, its meaning cannot be easily paraphrased, or for a stylistic reason.

\section{Previous Studies in the Context of English - Indonesian Language Pairs}

In the English - Indonesian language pairs, some studies have previously been conducted. Noorsavitri (2018) focused on the types of idioms and the translation strategies in translating the idioms in a romantic novel. She used theory from McCarthy and O'Dell (2010) to classify the types of idioms in the novel. Her findings showed 99 data of idiomatic expressions and the novel tends to use compound idioms. Further, translation by paraphrase is the most frequently used in translating the idioms in the novel.

Wicaksono \& Wahyuni (2018) conducted an analysis of idioms in Indonesian folklores. Their study focused only on the translation strategies in translating idiom from Indonesia into English. The findings suggested that idiomatic expression translation strategy by paraphrasing is the most dominant strategy used by the translator in translating the idiomatic expression found in five Indonesian folklores. 
Another study investigated Indonesia-English translation of idiomatic expressions, focusing on the idioms, in one of Indonesian best seller fiction story, Bumi Manusia which was translated into English as This Earth of Mankind. This study by Floranti \& Mubarok (2020) identified the types of the translation strategies to reproduce the idioms from SL in TL and the accuracy level of their latest meanings in TL. Their results showed that most of the idioms achieved equivalent meanings, but decreased meanings were unavoidable. Thus, it can be seen that the translator attempted to recreate the similar equivalence meaning of the idioms from SL through paraphrasing strategy instead of omitting the idioms in TL. Most of the translated idioms could be reproduced similarly with the original idioms.

Those previous researchers' work recognized the analysis of idiomatic expressions in literary work. However, the practical application in subtitling has not yet been widely clarified. The purpose of this paper is to reveal the use of idioms in movie subtitle along with the strategies of translating them.

\section{Method}

This present study utilized Baker's and Seidl \& McMordie theories as its frameworks. With respect to the analysis of the source text and the target text utterances in terms of the idiomatic expressions, this study was rooted in the framework of qualitative research. In order to quantify the qualitative data gathered, and to present them in a more meaningful way, frequency and percentage were used. With respect to the first research question, types of idioms were referred to Seidl \& McMordie's (1988). Meanwhile, for the second research question, using Baker's (2018) theory, the subtitles of the movie were analyzed, and the types of idiomatic expression were determined. After determining the types and translation strategies, a conclusion was made.

\section{Findings and Discussion}

In the following data, SL stands for Source Language (in this case, English), and TL stands for Target Language (in this case, Indonesian).

\section{Types of Idioms}

\section{Keywords with Idiomatic Uses}

This type of idiom deals with a selection single words which are known to present difficult because of their particular idiomatic meanings. Also, this type of idiom uses adjective, nouns, and miscellaneous words as the main subject.

SL: I speak my mind now.

TL: Aku bebas berpendapat.

The idiom 'speak my mind' is an expression when someone say openly what they think or feel. This expression uses the word 'mind' as the idiomatic uses. 'Mind' is the main subject and it is classified in the subtype of particular words with special idiomatic uses; noun with special idiomatic uses. 
SL: How dare you accuse me!

TL: Beraninya kau menuduhku!

The idiom 'how dare you' uses the word 'how' as the idiomatic element. 'How' is the main subject and it is classified in the subtype of particular words with special idiomatic uses; Miscellaneous words with special idiomatic uses. 'How dare you' is an idiomatic expression that show annoyance to others' rudeness.

\section{Idioms with Nouns and Adjectives}

SL: But my beginner's luck has panned out.

TL: Tapi aku punya keberuntungan pemula.

In this excerpt, the idiom 'beginner's luck' is a compound noun. The meaning of 'beginner's luck is unexpected success in someone's first attempt at doing something. This expression is used by Mr. Ratchett when telling his experience as a businessman, and he just started as an art dealer and he was successful even though he was just a beginner in this field.

\section{Idiomatic Pairs}

SL: Consigned to wine and dine handsome officials for all eternity.

TL: Mengajak makan dan minum para pejabat untuk selamanya.

The idiom 'wine and dine' is formed by pairing two nouns 'wine' and 'dine'. 'Wine and dine someone' is an expression that is used when somebody is trying to entertain someone by offering them drinks or a meal (Siefring, 2004). This expression was used by Mr. Bouc when he told Mr. Poirot that he was going to have a meal with the officials in the Orient Express train.

\section{Idioms with Prepositions}

SL: ... and monster them till they have the world down cold.

TL: ... lalu memaksa mereka menghafal dunia.

'down cold' begins with the preposition 'down' as the main part of the idiom. 'Down cold' means someone learned, mastered, or understood perfectly on something (Farlex Dictionary of Idioms, 2015). In one of the scenes, this expression is used by Ms. Debenham when she was explaining about her job as a governess and she would start teaching geography first, then she would teach her students until they understand it completely and perfectly.

Another example of this type of idiom is:

SL: No, after you.

TL: Tidak, silakan.

In this excerpt, 'after you' begins with a preposition 'after' as the main part of the idiom. The idiom 'after you' means someone politely urges another person to do something first (Farlex Dictionary of Idioms, 2015). This expression, in the movie, was used by Mr. Ratchett when he politely gave Mr. Poirot a way to his cabin. 


\section{Phrasal Verbs Idioms}

In this type, the idiom is formed when it is organized by a verb. A verb can be considered as a phrasal verb if it consists of two or more words. One of these words must be a verb, while the other can be an adverb, a preposition, or both an adverb and a preposition. Sometimes, the combination of verb + preposition of particle results in a separated unit of meaning, which may be highly idiomatic.

SL: And when it is not, the imperfection stands out..."

TL: Ketika tidak semestinya, kecacatannya akan menonjol...”

The idiom 'stands out' consists of a verb 'stand' and a preposition 'out'; therefore, the idiom can be classified as Phrasal Verbs Idioms. According to Seidl and McMordie (1988, p.146), the idiom 'stand out' means be very noticeable or conspicuous.

SL: You know, with your books and your capers, you are missing out on romance.

TL: Dengan bukumu dan makananmu, kau melewatkan asmara.

The phrase 'missing out' can be classified as Phrasal Verbs Idioms, meaning someone has not experienced something or not profit from something.

\section{Verbal Idioms}

There are two combinations to form a verbal idiom. The combinations are verb with a noun and verb with a prepositional phrase.

SL: I don't quite see the point of your question.

TL: Aku tak mengerti arah pertanyaanmu.

The phrase 'see the point of something' can be classified into Verbal Idioms in Verb + Noun. The idiom means to understand or appreciate the meaning, reason, or importance of something (Farlex Dictionary of Idioms, 2015).

SL: He can see right through us.

TL: Dia bisa membaca pikiran kita.

The idiom 'see right through us' consists of a verb 'see' and a preposition phrase 'through us' therefore, the idiom can be classified as Verbal Idioms in Verb + Preposition Phrase. 'See right through us' or 'see through someone' means to understand or detect the true nature of someone (Spears, 2005).

\section{Idioms from Special Subjects}

SL: He is on holiday.

TL: Dia sedang berlibur.

In this excerpt, the idiom 'on holiday' can be classified into Idioms with Special Subjects in Travel subject because the idiom is related to travel. According to Farlex Dictionary of Idioms (2015), 'on holiday' means spending time away from work or school, especially to travel some place for 
recreation. The idiom was used by Mr. Poirot when someone looked for him for another case to handle it, but Mr. Poirot said that he was on holiday which means he did not want to take any cases for a while.

\section{Idioms with Key Words from Special Categories}

SL: You're an odd bird there.

TL: Kau orang yang aneh.

The idiom 'an odd bird' can be classified as Idioms with Key Words from Special Categories in the Animal category since the word 'bird' is related to the category. 'An odd bird' means an eccentric person whose behavior or way of life is regarded as strange (Seidl \& McMordie, 1988, p.197).

SL: I would like to hire you to watch my back...

TL: Aku ingin menyewamu untuk menjagaku...

In this excerpt, the word 'back' is related to the part of the body category, so the idiom can be classified as Idioms with Key Words from Special Categories. The idiom 'watch someone (or your) back' means protect someone else (or yourself) against danger from an unexpected quarter (Siefring, 2004). The idiom was used by Mr. Ratchett when he wanted to hire Mr. Poirot to protect him from someone who wants to kill him.

\section{Idioms with Comparison}

SL: Mrs. Hubbard wants to speak to you. I held her as best as I could.

TL: Ny. Hubbard ingin bicara. Aku sudah berusaha menahannya.

'As best as I could' has a pattern 'as + Adjective + as + Noun', so this idiom can be categorized as comparison with 'as... as'. According to Farlex Dictionary of Idioms (2015), the idiom 'as best as I could' means to the best of someone's abilities. In the movie, this expression was used by one of the train conductors, Michel, when he told Mr. Poirot that Mrs. Hubbard insist wanted speak with him, but Michel could not hold Mrs. Hubbard anymore to not speak with Mr. Poirot.

With respect to the first research question, the findings of the study indicated that among Seidl \& McMordie's (1988) types of idioms, all involved in this movie subtitle. Table 1 shows the frequencies and percentages of the categories of idioms.

Table 1. Frequency and percentage of each type of idiom

\begin{tabular}{|c|l|c|c|}
\hline No & \multicolumn{1}{|c|}{ Types of Idioms } & Frequency & Percentage \\
\hline 1 & Keywords with Idiomatic Uses & 16 & $21 \%$ \\
\hline 2 & Idioms with Nouns and Adjectives & 2 & $3 \%$ \\
\hline 3 & Idiomatic pairs & 1 & $1 \%$ \\
\hline
\end{tabular}

Arab World English Journal for Translation \& Literary Studies

ISSN: 2550-1542 | www.awej-tls.org 
AWEJ for Translation \& Literary Studies Volume, 5 Number 1. February 2021

Translation of Idioms: How They are Reflected in Movie Subtitling

Manipuspika \& Winzami

\begin{tabular}{|c|l|c|c|}
\hline 4 & Idioms with Prepositions & 7 & $9 \%$ \\
\hline 5 & Phrasal Verbs Idioms & 26 & $34 \%$ \\
\hline 6 & Verbal Idioms & 5 & $6 \%$ \\
\hline 7 & Idioms from Special Subjects & 1 & $1 \%$ \\
\hline 8 & Idioms with Key Words from Special Categories & 16 & $21 \%$ \\
\hline 9 & Idioms with Comparison & $\mathbf{7 7}$ & $\mathbf{1 0 0 \%}$ \\
\hline & Total & & $4 \%$ \\
\hline
\end{tabular}

Translation Strategies of Idiomatic Expressions

1. Using an Idiom of Similar Form and Meaning

This translation strategy involves using an idiom in the TL that has the same meaning as the SL idiom. Also, the idiom in TL must consist of lexical items that is equivalent to the idiom in SL.

SL: How dare you accuse me!

TL: Beraninya kau menuduhku!

In this excerpt, the idiom 'how dare you' is an idiomatic expression that shows annoyance to others' rudeness. The idiomatic expression 'beraninya kau' is also often used to express annoyance to others' rudeness in the target language. Therefore, the translation of 'how dare you to accuse me!' into 'beraninya kau menduhku!' has both equivalent meaning and lexical item with the SL.

\section{Using an Idiom of Similar Meaning but Dissimilar Form}

This strategy is translating idiom by using an idiom with similar meaning but dissimilar form in the target language. In this case, the lexical items of an idioms are not preserved, therefore it is translated as a semantic equivalent.

SL: I've got three religions bent on riot.

TL: Ada tiga agama siap buat kericuhan.

According to Spears (2005), 'bent on riot' or 'bent on doing something' means determined to do something. Therefore, the translator translated the idiom as 'siap buat kericuhan' which has an equivalent meaning with the idiom 'bent on riot', but the translation has different lexical item from those in the source language.

3. Translation by Paraphrase

Paraphrasing idioms is the best way to deliver the message contained in the SL idiom using different words and grammatical structures in the TL.

SL: I want to look at paintings and have too much time on my hands.

Arab World English Journal for Translation \& Literary Studies

ISSN: 2550-1542 | www.awej-tls.org 
TL: Aku ingin melihat-lihat lukisan dan punya banyak waktu luang.

The idiom 'have too much time on someone's hand' means to have extra time or have time to spare. The translator translated the idiom 'have too much time on my hands' into 'punya banyak waktu luang'. There is no match found in TL, so different words and grammatical structure from the SL idiom is used.

\section{Translation by Omission}

SL: I may not be good for much, but I sure as hell can get you a bed on my train...

TL: Aku hanya orang biasa, tapi aku bisa carikan kamar di keretaku...

In this translation, the translator omitted the idiom 'sure as hell' that is used to emphasize something. In this case, the idiom is used by Mr. Bouc that he was really sure that he could find room for Mr. Poirot. This expression has no equivalent lexical items and becomes redundant in the target language; therefore, the translator omitted the idioms for stylistic purpose.

With regard to the second research problem, the findings of the study indicated that from Baker's (2018) 4 translation strategies, translating by paraphrase was more beneficial for translating idiomatic expressions. Table 2 shows the frequencies and percentages of the translation strategies involved in the translation of idiomatic expressions.

Table 2. Frequency and percentage of each translation strategy

\begin{tabular}{|c|l|c|c|}
\hline No & \multicolumn{1}{|c|}{ Strategies of Translating Idioms } & Frequency & Percentage \\
\hline 1 & Using an Idiom of Similar Form and Meaning & 7 & $9 \%$ \\
\hline 2 & Using an Idiom of Similar Meaning but Dissimilar Form & 25 & $32 \%$ \\
\hline 3 & Translation by Paraphrase & 43 & $56 \%$ \\
\hline 4 & Translation by Omission Total & 2 & $3 \%$ \\
\hline & \multicolumn{2}{c|}{ T7 } & $\mathbf{1 0 0 \%}$ \\
\hline
\end{tabular}

\section{Discussion}

With reference to the results of analysis, phrasal verbs idioms, idioms with key words from special categories, and keywords with idiomatic uses are among the highly frequent idiom categories used in this particular movie. This, in turn, affects the strategies of translating the idioms; Translation by Paraphrase was the very highly frequent translation strategy, taking more than 50\% occurrences. On the other hand, Using an Idiom of Similar Meaning but Dissimilar Form is located in the high-frequency position of the continuum. Furthermore, Using an Idiom of Similar Form and Meaning and Translation by Omission are the translation strategies of low frequency. 
It was revealed that all types of the idioms were found in Murder on the Orient Express movie. Phrasal verbs idiom is the most frequently type of idiom that occurred in the movie. This result was in line with Seidl \& McMordie's (1988) statement that idioms are mostly organized by verbs and a verb can be considered as a phrasal verb if it consists of two or more words. One of these words must be a verb, while the other can be an adverb, a preposition, or both an adverb and a preposition.

In addition, all strategies of translating idiomatic expressions proposed by Baker (2018) were employed in the movie subtitle. Translation by paraphrase (56\%) was found to be the most frequently used by the translator to translate the idioms. It is because there are cultural differences between the SL and the TL, and sometimes translators might find it difficult to find the exact translation of the idioms. Therefore, the translator often uses this strategy in order to convey the meaning of the utterances as clearly as possible.

The result of this present study strongly supported Fitri et.al (2019) revealing that translation by paraphrase is the most preferred strategies in translating English idioms into non-idiomatic expression in Indonesian language. As Baker (2018) indicated that translation by paraphrase is the most common way of translating SL idioms which do not have the equivalent in TL. It is not easy to find the equivalent of SL idiom or there is no appropriate idiom and then transferred it into TL idiom. Hence, the translator tries to render the meaning of source text (ST) idiom using words in TL which are similar or close in meaning to ST, but the words do not make up an idiom.

The second most used strategy (32\%) was translating using an idiom of similar meaning but dissimilar form. In this strategy, the lexical items of the idioms are not preserved, therefore it is translated as a semantic equivalent. The third position was the translation using an idiom of similar form and meaning (9\%). Even though Baker (2018) argued that this strategy is most unlikely used, this present study found its application in the movie subtitling. Finally, the least strategy employed was translation by omission. Omission may be used when there is no close equivalent meaning and style in the target language.

Idioms are expressions that are culture-bound; therefore, it will not be wrong to say that culture is most complex topic to deal with translation. This is in line with Hassan \& Tabassum' (2014) study stating that culture is an umbrella term and translators confront the problems of mixing between connotations and denotative meanings of words, forms and address and the hurdles related with metaphors and idioms.

This study finding also confirms a previous study from Wicaksono \& Wahyuni (2018) that translation by paraphrase is the most common strategy in translating the idioms. The underlying reason is because translation by paraphrase is the flexible strategy to translate the idioms and the translation will be more acceptable and it is easier for TL readers to understand. The difference of the finding may be explained from the variability of the research objects, for instance, folklores, 
novels, etc. This present study also came up with results in line with Mabruroh's (2015) study revealing that the dominant type of idiom used in 'The Adventures of Tom Sawyer' novel is phrasal verb idiom with 446 idioms (56.03\%).

Lastly, this current study results agreed with Baker (2018) saying that idioms allow little or no variation in form and, in the case of idioms, often carry meanings which cannot be deduced from their individual components. Idioms and fixed expressions cannot be formally translated because their forms are misleading. It is the content and the cultural background that matter.

\title{
Conclusion
}

Phrasal verbs idioms are the most frequent type of idiom used in the movie with the occurrences of 26 out 77 idioms. It is because most idioms were organized by a verb comprising the combination of verb and preposition or verb and adverb. Furthermore, translation by paraphrase is the most frequently used by the translator in translating the idioms in Murder on the Orient Express movie with the occurrences of 43 out of 77 idioms. Due to the different culture between the SL and TL, the translator tends to paraphrase the English idiom into Indonesian. Translation by paraphrase can be used when the translator cannot find the suitable translation idioms in the TL, so they can paraphrase the meaning of the idiomatic expression to the target language, which is Indonesian in this case. Recommendation is addressed to future researchers, in which further study should address a comparative analysis to show how idiomatic expressions are translated differently in different objects.

\begin{abstract}
About the Authors;
Yana Shanti Manipuspika is a lecturer in Study Program of English, Faculty of Cultural Studies Universitas Brawijaya, Malang, East Java, Indonesia. She earned her Master's Degree (2009) in Applied Linguistics from The University of Newcastle, Australia. Her research and teaching interests include Second Language Acquisition (SLA), Pragmatics, and Translation Studies. ORCiD: https://orcid.org/0000-0002-3885-7232
\end{abstract}

Damai Reska Julia Winzami graduated with a bachelor's degree from Universitas Brawijaya, Indonesia in 2020. She earned a Bachelor of Arts in English language, in linguistics concentration. ORCiD: https://orcid.org/0000-0002-7448-9369

\section{References}

Baker, M. (2018). In Other Words: A Course book on Translation (Third Edition). London and New York: Routledge.

Farlex Dictionary of Idioms. (2015). Retrieved April 12020 from.

https://idioms.thefreedictionary.com/ 
Fitri, O.M., Faridi, A., \& Hartono, R. (2019). Baker's Strategies Used in Translating English Idioms into Indonesian in Crazy Rich Asians by Kevin Kwan. English Education Journal, 9 (3), $342-353$.

Floranti, A.D. \& Mubarok, Y. (2020). Indonesia-English Translation of Idiomatic Expressions in The Novel 'This Earth of Mankind'. Buletin Al-Turas, 26 (2), 207-220.

Hassan, S.M. \& Tabassum, M.F. (2014). Strategies of Translating Idioms. British Journal of English Linguistics, 2 (3), 14-29.

Jabbari, M.J. (2016). Idiomatic Expressions in Translation. Journal of Advances in Humanities, 4 (3), 507-514.

Nida, E.A., \& Taber, C.R. (1982). The Theory and Practice of Translation. Leiden: E.J. Brill

Mabruroh, K. (2015). An Analysis of Idioms and Their Problems found in the Novel the Adventures of Tom Sawyer by Mark Twain. Rainbow: Journal of Literature, Linguistics and Cultural Studies, 4 (1), 1-11.

Noorsavitri, P. (2018). Translation Analysis of Idiomatic Expressions Found in Jojo Moyes' "Me Before You" Novel. Undergraduate Thesis. Malang: Faculty of Cultural Studies Universitas Brawijaya.

Seidl, J. \& McMordie, W. (1988). English Idioms and How to Use Them. Oxford: Oxford University Press.

Shojaei, A. (2012). Translation of Idioms and Fixed Expressions: Strategies and Difficulties. Theory and Practice in Language Studies, 2 (6), 1220-1229.

Siefring, J. (2004). Oxford Dictionary of Idioms, 2nd Edition. Oxford: Oxford University Press.

Spears, R.A. (2005). McGraw-Hill's Dictionary of American Idioms and Phrasal Verbs. New York: The McGraw-Hill Companies.

Wicaksono, D.B \& Wahyuni, E. (2018). An Analysis of the Strategies Used in Translating Idioms in Indonesia into English Found in Indonesian Legends. CELTIC: A Journal of Culture, English Language Teaching, Literature \& Linguistics, 3 (1), 45-55. 